\title{
Barbara Mróz-Gorgoń
}

Uniwersytet Ekonomiczny we Wrocławiu

e-mail: barbara.mroz-gorgon@ue.wroc.pl

\section{Grzegorz Szymański}

Politechnika Łódzka

e-mail: grzegorz.szymanski@p.lodz.pl

\section{CORPORATE REBRANDING - STRATEGIA ROZWOJU. ANALIZA PRZYPADKU FIRMY ZABERD S.A. \\ CORPORATE REBRANDING - STRATEGY OF DEVELOPMENT. THE ANALYSIS OF ZABERD S.A. CASE}

DOI: $10.15611 /$ pn.2018.526.27

\begin{abstract}
Streszczenie: Turbulentne otoczenie skłania do wzmożonych poszukiwań nowych formuł działania podmiotów gospodarczych. Rebranding może być wprowadzany zarówno w formie drobnych zmian (kosmetyczna zmiana komunikacji wizualnej), jak i całkowitej zmiany nazwy i całej filozofii marki. W ostatnim okresie nastąpił wyraźny wzrost liczby renomowanych marek, które wprowadziły rebranding. Artykuł został oparty na systematycznej analizie literatury i na analizie przeprowadzonych badań, które dotyczyły percepcji marki ZABERD S.A. Celem artykułu jest przybliżenie determinant oraz problematyki i sposobu budowania strategii rebrandingu na przykładzie marki ZABERD S.A., a także wyłonienie implikacji menadżerskich o charakterze aplikacyjnym. Strategia rozwoju może odnieść długofalowy sukces jedynie wtedy, gdy wprowadzony zostanie również proces rebrandingowy, który wpływa na zmiany m.in. dwóch kluczowych obszarów: kultury organizacyjnej, a w tym rutyn organizacyjnych, oraz sposobu zarządzania w firmie.
\end{abstract}

Słowa kluczowe: branding, kreowanie wizerunku marki, strategia, rebranding, zarządzanie.

Summary: A turbulent environment determines the increased search for new formulas of operation of business entities. Rebranding can be introduced both: in the form of small changes (cosmetic change in visual communication), up to a complete change of the name and brand philosophy. In recent years there has been a marked increase in the number of renowned brands that have introduced rebranding. The article was based on a systematic analysis of the literature and on the analysis of the conducted research, which concerned the perception of the ZABERD S.A. brand. The aim of the article is to present the determinants as well as the issues and the method of building a rebranding strategy on the example of the ZABERD S.A. brand, 
as well as to determine the application implications of management. The development strategy can only achieve long-term success if a rebranding process is introduced, which affects changes, including two key areas: organizational culture, including organizational routines and the management system in the company.

Keywords: branding, brand image creation, strategy, rebranding, management.

Jeśli marka nie jest niczym więcej, jak tylko nazwa, to jako marka jest klęska.

[Kotler 1999, s. 93]

\section{Wstęp}

W dzisiejszym niepewnym otoczeniu widoczne jest wzmożone poszukiwanie wciąż nowych formuł działania podmiotów gospodarczych, w tym nowych sposobów kreowania wizerunku i innowacyjnych metod dotarcia do klientów. Intensyfikowane są również poszukiwania nowatorskich rozwiązań w procesie pozycjonowania i „,budowania marki w umysłach konsumentów" [Ries, Trout 1982]. Dążenie do zwiększenia wartości marki i wzmacniania więzi pomiędzy marką a konsumentami przejawia się również poprzez nowe strategie brandingowe, które mają na celu wyróżnienie i odróżnienie [Kapferer 1995] danej marki od konkurencji, jak również kształtowanie oferty i image'u przedsiębiorstwa, prowadzące do zajęcia wyraźnego, znaczącego miejsca w pamięci odbiorców docelowych [Kotler 1994]. Powyższe zagadnienia są przedmiotem zainteresowania i rozważanań zarówno praktyków, jak i teoretyków z obszaru zarządzania i marketingu.

Niniejszy artykuł został oparty na systematycznej analizie literatury krajowej i zagranicznej oraz na analizie przeprowadzonych badań o charakterze pierwotnym, które dotyczyły percepcji marki ZABERD S.A. wśród konsumentów (badanie ankietowe: $\mathrm{N}=500$ ) oraz wśród pracowników firmy ZABERD S.A. (badanie ankietowe: $\mathrm{N}=150$, wywiady pogłębione -12 wywiadów). Badania były prowadzone w okresie luty-kwiecien 2016 oraz marzec-listopad 2017 r. Przy realizacji badania i przygotowania kwestionariusza ankiety (badania ankietowe) zaangażowani byli studenci koła naukowego Zarządzania i Marketingu: „PRoMOTION”, działającego na Wydziale Nauk Ekonomicznych Uniwersytetu Ekonomicznego we Wrocławiu.

Celem artykułu jest przybliżenie determinant oraz problematyki i sposobu budowania strategii rebrandingu na przykładzie marki ZABERD S.A. (Zakład Bezpieczeństwa Ruchu Drogowego), a także wyłonienie implikacji menadżerskich o charakterze aplikacyjnym dla innych przedsiębiorstw podejmujących w przyszłości działania rebrandingowe. 


\section{Rebranding jako filar strategii rozwoju}

Jednym z najważniejszych i bardzo widocznym narzędziem marketingowego oddziaływania na rynek i konsumentów jest marka [Szwajca 2009]. Marka (brand) jest najważniejszym instrumentem współczesnego marketingu - jego centralnym punktem, bez którego nie można już sobie wyobrazić działań promocyjnych ani też prowadzenia biznesu w warunkach rynkowej konkurencji [Zboralski 2000, s. 29]. Wizerunek marki (brand image) to obraz, jaki ma marka w świadomości uczestników rynku. Obraz ten jest tworzony przez oddziaływanie odpowiednio dobranymi elementami marketingu-mix, wynikającymi z przyjętej przez firmę strategii marketingowej. Na wizerunek marki składa się znajomość marki i jej prestiż (renoma) wśród konsumentów, pośredników handlowych, konkurentów rynkowych. Jeśli konsumenci są świadomi marki, ma ona w ich opinii atrakcyjny wizerunek, lepszy niż wizerunki innych marek, to częściej wybierają i dokonują zakupu oznaczonych nią produktów. Marka ze zwykłego oznakowania produktu staje się wtedy rozpoznawalnym wyróżnikiem produktów, które są poszukiwane i pożądane przez konsumentów [Czubała (red.) 2012, s. 99].

Idea marek jako podstawowego zasobu, od którego zależy sukces korporacyjny, jest głęboko zakorzeniona w nowoczesnej kulturze korporacyjnej, a także stanowi centralny element dyscypliny marketingowej. Kolejnym założeniem, które leży u podstaw teorii marketingu i praktyki biznesu, jest to, że silne marki są budowane przez wiele lat ciągłych inwestycji, i jeśli są dobrze zbudowane, tzn. jeśli tożsamość marki zaprojektowana przez architektów marki pokrywa się lub jest podobna do jej wizerunku odbieranego przez konsumentów, przyniosą lojalną grupę konsumentów i wpłyną na wartość marki (brand equity), która wyznaczana jest na podstawie stopnia lojalności klientów, świadomości nazwy, postrzeganej jakości produktu, siły skojarzeń nabywców oraz pozostałych aktywów, takich jak patenty, znaki handlowe i relacje z uczestnikami kanałów dystrybucji [Nowak (red.) 2011]. Wartość marki określana jest również często kapitałem marki i przedstawiana jest $\mathrm{w}$ tym ujęciu jako zestaw aktywów i pasywów przedsiębiorstwa związanych z marką, jej nazwą lub symbolem, który powiększa lub pomniejsza wartość dostarczaną przez produkt dla firmy lub jej klientów [Niestrój (red.) 2009, s. 248].

Działania dotyczące budowania marki mają również na celu zapewnienie: wysokiej sprzedaży, dużego udziału w rynku i ciągłego strumienia dochodów właścicielowi marki i powinny być skomponowane holistycznie jako system działań, nazywany procesem brandingowym, który sięga do głębi marki, czyli do jej istoty - rdzenia marki (brand essence). Rdzeń marki stanowi najważniejszy (najpowszechniejszy) aspekt postrzegania i oceny danej marki, w zasadniczy sposób określając jej wartość dla odbiorców rynkowych i wyróżniając ją spośród marek konkurencyjnych. Może mieć charakter obiektywny (np. cechy fizyczne, walory funkcjonalne, styl obsługi, zakres oferty) lub/i subiektywny (emocjonalne atrybuty wizerunku) [Zboralski 2000, s. 261]. Ponadto działania brandingowe powinny pozostawać w relacji z uruchamia- 
niem procesu pozycjonowania marki (plasowanie marki - brand positioning), czyli kreowania poprzez narzędzia i metody marketingowe wizerunku: produktu, marki lub firmy [Trout 1969, s. 52]. Pozycjonowanie marki ma na celu trwałe wyrycie się w pamięci konsumentów, by mogli oni odróżnić daną markę od marek konkurencyjnych, innymi słowy, by zająć optymalną pozycję na mapie percepcji rynkowej. Powodzenie tego procesu uzależnione jest właściwego rozpoznania tzw. preferowanych walorów marki (brand preference), które to stanowią pożądane przez docelowego odbiorcę marki korzyści (cechy) obiektywne lub subiektywne, z których powodu mająca je marka będzie wyżej ceniona od marek konkurencyjnych. Decydują one o postrzeganiu wartości marki; mogą dotyczyć m.in. funkcji użytkowych, składu, konstrukcji, poziomu technicznego, prestiżu, atrybutów psychologicznych [Zboralski 2000, s. 267]. Owo postrzeganie przekłada się natomiast na świadomość marki określaną poprzez różne stopnie. Są to: rozpoznawalność marki (brand recognition), przypominalność marki (brand recall) oraz pamięć spontaniczna marki w umyśle konsumenta (top of mind). Dla każdego stopnia świadomości marki istnieją dodatkowo inne miary [Urbanek, Kosińska (red.) 2002, s. 170].

Nie zawsze jednak zbudowana tożsamość marki pokrywa się z jej wizerunkiem (i świadomością), co może powodować niechciane postawy wobec marki (brand attitude), które rozumiane są jako względnie trwała struktura opinii, wyobrażeń i odczuć, w których wyraża się poznawczo-emocjonalno-wolicjonalny stosunek klienta do danej marki. Jest reakcją na wizerunek, a pośrednio na wartość marki, i kształtuje zachowania nabywczo-konsumpcyjne, m.in. lojalność wobec marki (brand loyalty) [Zboralski 2000, s. 266].

Zdarza się również, że architektura marki i działania brandingowe nie odpowiadają współczesnym (w danym okresie) trendom rynkowym. Wtedy oprócz zastosowania strategii pozycjonowania adaptacyjnego, czyli jak stwierdza L. Garbarski, strategii, która jest stosowana właśnie w sytuacjach, w których - w następstwie ewolucji potrzeb rynku docelowego - dokonuje się zmiany pozycji na rynku. Te kolejne zmiany są często określane jako repozycjonowanie (powtórne pozycjonowanie produktu). Strategia repozycjonowania jest dość często związana z próbą zmiany pozycji produktów konkurentów przez wyraźne odróżnienie ich od produktu przedsiębiorstwa. Dzieje się tak np. dzięki wyszukaniu słabych stron produktów konkurentów i umocnieniu pozycji własnego produktu poprzez działania obniżające w oczach potencjalnych nabywców wartość produktów konkurentów [Garbarski (red.) 2011, s. 191]. Wszystkie przywołane sytuacje stanowią tzw. „wyzwalacze procesu rebrandingu" [Miller, Merrilees, Yakimova 2014] i odbierane są jako sygnał do swoistej restrukturyzacji marki, czyli rebrandingu, który często bywa mylony z repozycjonowaniem.

Repozycjonowanie jest definiowane przez badaczy jako zmiana działalności podstawowej. Innym zagadnieniem jest również rekoncentracja, która polega na rezygnacji z działań peryferyjnych na rzecz działalności podstawowej [por. Decker, van der Valden 2006, s. 15]. Oba zjawiska, zarówno repozycjonowanie, jak i rekon- 
centracja, mogą stanowić kluczowy element strategii rebrandingowej, lecz same nie stanowią o rebrandingu marki.

Rebranding jest pojęciem głębszym i oznacza zmianę filozofii marki. Jak stwierdza E. Jaska, rebranding można zatem nazwać procesem zmiany modelu biznesowego firmy i sposobu konkurowania oraz integrowaniem wizerunku ze strategią firmy [Jaska 2014, s. 78]. Rebranding powinien zawsze wyjaśniać i precyzować pozycjonowanie. Samo twierdzenie, że dana marka jest najlepsza, jest bezsensowne, a używanie pustych słów, takich jak „najlepsza wartość" i "wyjątkowa obsługa klienta”, nie wygeneruje innych postaw poza wzmożonym sceptycyzmem. Rebranding powinno się wykorzystać jako inicjatywę, aby zmusić się do przemyślenia filozofii marki, do lepszego jej zdefiniowania i wsparcia wiedzy na temat marki [Iverson, McLeod, Erwin 1996, s. 38].

Ważnym zagadnieniem jest również odróżnienie tzw. rebrandingu korporacyjnego (corporate rebranding) od rebrandingu marek produktowych, na co wskazali już wcześniej inni badacze [Balmer 2001]. Marka korporacyjna może być zdefiniowana jako taka, która posiada dwa kluczowe wymiary, są to: zewnętrzna percepcja tej marki to jej wizerunek (brand image); wewnętrzna percepcja, odpowiadająca na pytanie „Jak siebie sami postrzegamy?”, stanowi jej tożsamość (identity). Zatem rebranding korporacyjny dotyczy modyfikacji tożsamości marki (the perceived self), i prezentacji tego odmienionego wizerunku wewnątrz całej organizacji poprzez odmieniony wizerunek wewnętrznej marki (the core-self). Jak wskazują badacze, w celu zrozumienia potrzeby rozróżnienia tych percepcji należy studiować kolejne przypadki umożliwiające wyodrębnianie determinant i faktorów podejmowanych decyzji rebrandingowych [Singh, Tripathi, Yadav 2012, s. 92]. Przedstawione badania i analiza przyczyniają się zatem do wypełnienia tej, wskazanej przez badaczy problematyki rebrandingu, luki, bowiem firma ZABERD S.A. działa głównie w oparciu o system przetargów publicznych, realizując w znacznej mierze usługi związane $\mathrm{z}$ bezpieczeństwem i utrzymaniem dróg. Zatem w tym przypadku - zgodnie $\mathrm{z}$ definicją - mowa będzie o rebrandingu korporacyjnym.

\section{Rebranding na przykładzie firmy ZABERD S.A. - wyniki badań i analiza}

We wstępie zaznaczono już, że artykuł został oparty na systematycznej analizie literatury zarówno krajowej, jak i zagranicznej oraz na analizie przeprowadzonych badań o charakterze pierwotnym, które dotyczyły percepcji marki ZABERD S.A. Badania były prowadzone w okresie luty-kwiecień 2016 oraz 14.03-15.11.2017 r. w ramach programu „MOZART” z dotacji przyznawanej w drodze konkursu Miejskiego Programu Wsparcia Partnerstwa Szkolnictwa Wyższego i Nauki oraz Sektora Aktywności Gospodarczej (we Wrocławiu), edycja 2016/2017 na realizację projektu włączającego naukowca w prace rozwojowe realnie funkcjonującej firmy. 
Przedmiotem projektu w tym przypadku było opracowanie długoterminowej strategii rozwoju firmy ZABERD S.A., zwiększającej ilość klientów i zamówień oraz poziom zatrudnienia firmy, a także odbudowującej świadomość marki (rebrandingu korporacyjnego). W chwili przystąpienia do projektu firma ZABERD S.A. funkcjonowała na rynku, nie posiadając długookresowej strategii i nie dysponując również odpowiednio przygotowną jednostką organizacyjną, która mogłaby taki dokument przygotować i aktualizować. Badanie pilotażowe - badanie ankietowe wykonane na próbie 500 respondentów w wieku 20-55 lat (technika ankiety rozdawanej; metoda PAPI), w terminie: luty-kwiecien 2016 r. w trzech wrocławskich galeriach handlowych - wykazało niewielką wiedzę respondentów (mieszkańców miasta Wrocławia) o marce ZABERD S.A. (rys. 1), co wskazało na konieczność wprowadzenia działań rebrandingowych. Do realizacji badania i przygotowania kwestionariusza ankiety (badania ankietowe) zaangażowani byli studenci koła naukowego Zarządzania i Marketingu: „PRoMOTION”, działającego na Wydziale Nauk Ekonomicznych Uniwersytetu Ekonomicznego we Wrocławiu.

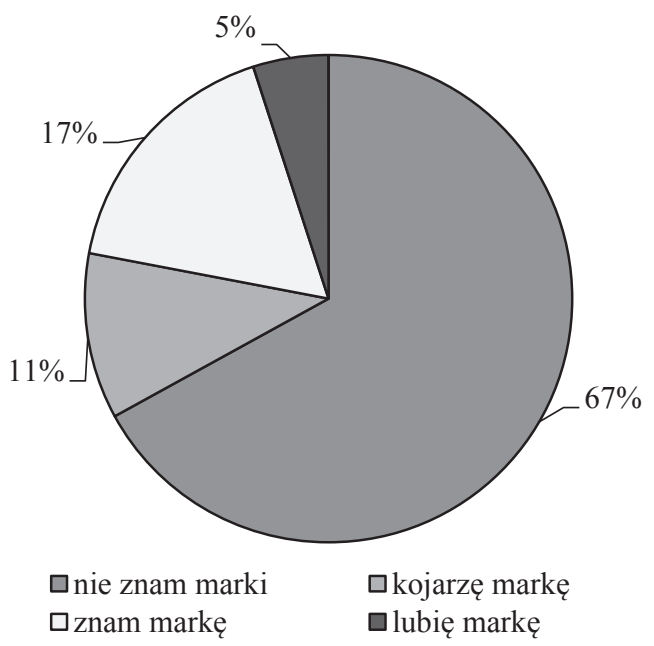

Rys. 1. Percepcja marki ZABERD S.A. wśród mieszkańców Wrocławia

Źródło: opracowanie własne na podstawie przeprowadzonych badań ankietowych.

Większość respondentów nie była w stanie odpowiedzieć, czym zajmuje się firma ZABERD S.A., natomiast respondenci, którzy rozpoznali markę, mieli do niej stosunek ambiwalentny.

W okresie od marca do listopada 2017 r. przeprowadzono badania ankietowe wśród pracowników (zarówno umysłowych, jak i fizycznych) firmy (badanie ankietowe; technika ankiety online; metoda CAWI; $\mathrm{N}=150$ ). I w tym przypadku wizerunek marki był niejasny, a znakomita większość pracowników określiła swój stosunek do niej jako ambiwalentny (rys. 2). 


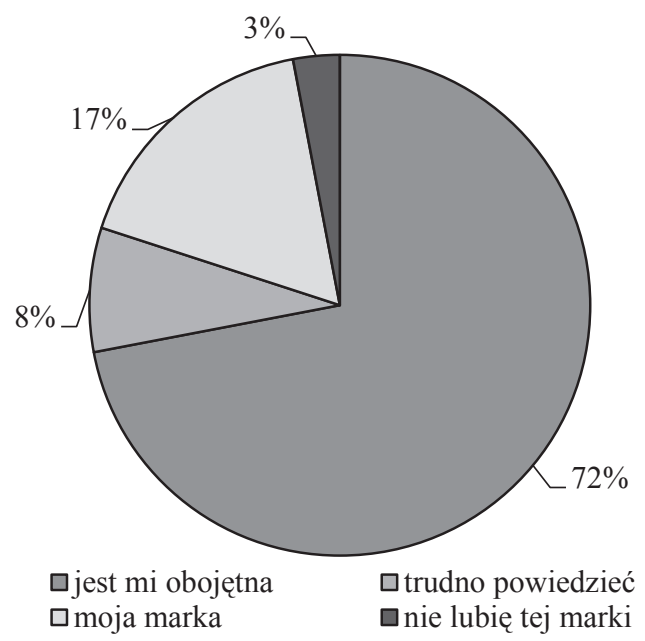

Rys. 2. Stosunek respondentów do marki ZABERD S.A. - wśród pracowników firmy

Źródło: opracowanie własne na podstawie przeprowadzonych badań ankietowych.

W ramach relizacji celu projektu przygotowano, w oparciu o analizy otoczenia zewnętrznego i wewnętrznego firmy, dokument strategii rozwoju. Przeprowadzono analizę konkurencji i trendów na rynku, w tym analizę PEST i SWOT; analizę komunikacji marketingowej tego rynku oraz opisane już badanie ankietowe wśród mieszkańców Wrocławia; przeprowadzono badania ankietowe wśród pracowników firmy (opisane powyżej) i przeprowadzono wywiady pogłębione z pracownikami administracji firmy w jej siedzibie (12 wywiadów).

Wywiady pogłębione (średni czas trwania ok. 2,5 godz. według wcześniej przygotowanego scenariusza) przeprowadzono zarówno z członkami zarządu firmy (prezes spółki i trzech członków zarządu, pełniących jednocześnie funkcje dyrektorów w firmie), jak i z kierownikami i pracownikami działów firmy. Zauważono istotne różnice w percepcji marki pomiędzy przedstawicielami kadry zarządzającej a pozostałymi członkami załogi. Elementem bardzo często podkreślanym w wywiadach z pracownikami niższego szczebla była słaba (lub jej brak) rozpoznawalność marki w opinii społecznej; podkreślano, iż mocny wizerunek marki miałby istotne znaczenie dla poczucia przynależności do marki i dumy z pracy dla niej. Przykładowe wypowiedzi: „kiedyś marka była lepiej postrzegana, była po prostu widoczna na ulicach. Dziś jest odwrotnie - nikt nie wie, co to za firma. Nie ma banerów, reklam na ulicach”; „chciałabym być dumna, że pracuję dla takiej marki, że reprezentuje coś, co znają wszyscy".

Również wskazano na istotny rozdźwięk pomiędzy postrzeganiem firmy przez pracowników oraz zarząd firmy - oprócz określeń użytych przez tych pierwszych: „firma z tradycją", „firma polska”, znalazły się też wypowiedzi nacechowane ambiwalentnymi lub też negatywnymi emocjami, jak np.: „firma jak każda inna. Nic 
szczególnego", „firma jak zakład pracy. Nikt nie wie, po co pracuje”. Pozytywny obraz firmy został przekazany w trakcie wywiadów z członkami zarządu, którzy używali takich sformułowań, jak: „,irma najlepsza na rynku”, ,lider w branży”, „,firma z silnym zespołem".

Jako główną słabą stronę kadra kierownicza wskazała problemy z usystematyzowaniem działań firmy (zarówno operacyjnych, jak i po części strategicznych). Wskazano na możliwe rozwiązanie tego problemu, jakim byłoby wprowadzenie systemu audytów wewnętrznych po przeprowadzonym projekcie - w tym analizy samego postępowania przetargowego - w celu analizy podjętych decyzji i działań, i tym samym wyeliminowania ewentualnych błędów w przyszłości oraz prowadzenia działań efektywniej. Według pracowników niższego szczebla główną słabą stroną firmy jest komunikacja i integracja zespołu - należy tu zaznaczyć, że również wśród kadry zarządzającej pojawiały się wątpliwości co do sposobu przekazywania informacji przez poszczególne działy. Taki stan budzi zaniepokojenie o możliwości i efekty implementacji strategii marketingowej i pozwala postawić tezę o konieczności podjęcia w tym zakresie odpowiednich działań doprowadzających do naprawy stanu komunikacji wewnętrznej firmy, co samo w sobie będzie jednym z filarów integrowania zespołu. Znakomita większość pracowników niższego szczebla i niektórzy reprezentanci kadry kierowniczej artykułowali potrzebę integracji zespołu.

Reasumując, wyniki przeprowadzonych badań ukazały konieczność wprowadzenia odpowiednich rutyn organizacyjnych (czyli charakterystycznego, konsekwentnie powtarzanego sposobu i stylu wykonywania danych czynności i działań) [Mitręga 2010], jak np. sposobu wprowadzania nowych działów, stanowisk, pracowników do firmy czy też przekazywania informacji dotyczących firmy (w zakresie jej wyników i zamierzeń). Strategia rozwoju może odnieść długofalowy sukces jedynie wtedy, gdy wprowadzony zostanie również proces rebrandingowy, który wpłynie na zmiany dwóch kluczowych w tym przypadku obszarów: kultury organizacyjnej, w tym rutyn organizacyjnych, oraz systemu zarządzania. Implementacja tych zmian powinna $\mathrm{w}$ długim okresie zwiększyć efektywności działań firmy ZABERD S.A., podejmowanych w obszarze rozwoju oferty i komunikacji marketingowej firmy, jak i zmienić wizerunek marki nie tylko wewnątrz firmy, ale również na zewnątrz.

\section{Podsumowanie}

Rebranding może być wprowadzany w formie zarówno drobnych zmian, takich jak kosmetyczna zmiana komunikacji wizualnej (restyling), jak i całkowitej zmiany nazwy i całej filozofii marki. Powtórna analiza, a w niektórych przypadkach zmiana wszystkich powiązanych z marką wartości i obietnic jest kluczowym elementem rebrandingu.

W ostatnim okresie nastąpił wyraźny wzrost liczby renomowanych marek, które wprowadziły rebranding. Próby zbudowania nowej marki, czasem nawet z dnia na 
dzień, wydają się sprzeczne z podstawowymi aksjomatami marketingu. Nasuwa się zatem pytanie: co dokładnie napędza tę falę rebrandingu i jakie są implikacje dla nowych marek? [Singh, Tripathi, Yadav 2012]. Jak wskazują badacze zajmujący się problematyką rebrandingu, dane dotyczących firm, które poddały się procesowi rebrandingowemu, stanowią cenne źródła wtórne i są również punktem wyjścia w empirycznych poszukiwaniach właściwości zjawiska rebrandingu. Dane te umożliwiają odpowiedź na pytanie, czy zmiana marki jest czymś bardziej rozpowszechnionym w poszczególnych branżach lub na poszczególnych rynkach geograficznych i czy konkretne warunki w branży wydają się przyspieszyć tę zmianę, jakie są określone motywacje firm podejmujących działania rebrandingowe [Singh, Tripathi, Yadav 2012]. Niniejszy artykuł wpisuje się w omawiany trend i stanowi nowy wkład do bazy danych dotyczącej tego zagadnienia.

Jak wynika z przeprowadzonych badań opisywanego przypadku, strategia rozwoju może odnieść długofalowy sukces jedynie wtedy, gdy wprowadzony zostanie również proces rebrandingowy, który wpływa na zmiany m.in. dwóch kluczowych obszarów: kultury organizacyjnej, a w tym rutyn organizacyjnych, oraz sposobu zarządzania w firmie.

\section{Literatura}

Balmer J.M.T., 2001, Corporate identity, corporate branding and corporate marketing: seeing through the fog, European Journal of Marketing, vol. 35, no. 3-4, s. 248-291.

Czubała A. (red.), 2012, Podstawy marketingu, Polskie Wydawnictwo Ekonomiczne, Warszawa.

Decker C., van der Velden R., 2006, Desinvestition von Unternehmensteilen aus der Sicht des Ressourcen und Kompetenzansatzes, [w:] Burmann C., Freiling J., Hülsmann M. (Hrsg), Neue Perspektiven des Strategischen Kompetenzmanagements, Strategisches Kompetenz-Management, DUV, Gabler Edition, Wissenschaft.

Garbarski L. (red.), 2011, Marketing. Koncepcja skutecznych dziatań, PWE, Warszawa.

Iverson R.D., McLeod C.S., Erwin P.J., 1996, The role of employee commitment and trust in service relationships, Marketing Intelligence \& Planning, vol. 14, no. 3, s. 36-44.

Jaska E., 2014, Znaczenie rebrandingu w kreowaniu wizerunku marki, Stowarzyszenie Ekonomistów Rolnictwa i Agrobiznesu, Roczniki Naukowe, tom XVI, zeszyt 1, Warszawa.

Kapferer J.N., 1995, Strategic Brand Management - New Approaches to Creating and Evaluating Brand Equity, Kogan Page, London.

Kotler P., 1994, Marketing. Analiza, planowanie, wdrażanie o kontrola, Gebethner \& Ska, Warszawa.

Kotler P., 1999, Kotler o marketingu. Jak kreować i opanowywać rynki, Wyd. Profesjonalnej Szkoły Biznesu, Kraków.

Miller D., Merrilees B., Yakimova R., 2014, Corporate rebranding: An integrative review of major enablers and barriers to the rebranding process, International Journal of Management, vol. 16, s. $265-289$.

Mitręga M., 2010, Zdolność sieciowa jako czynnik przewagi konkurencyjnej na rynku przedsiębiorstw, Prace Naukowe. Akademia Ekonomiczna w Katowicach, nr 237.

Niestrój R. (red.), 2009, Tożsamość i wizerunek marketingu, Polskie Wydawnictwo Ekonomiczne, Warszawa. 
Nowak E. (red.), 2011, Controlling $w$ działalności przedsiębiorstwa, Polskie Wydawnictwo Ekonomiczne, Warszawa.

Ries A., Trout J., 1982, Positioning: The Battle for You Mind, Warner Books, New York.

Singh A.K., Tripathi V., Yadav P., 2012, Rebranding and organisational performance - some issues of relevance, American Journal of Sociological Research, 2(5).

Szwajca D., 2009, Pozycjonowanie marki na rynku globalnym - możliwości i ograniczenia, Economy and Management, 1.

Trout J., 1969, Positioning is a game people play in todays' me-too market place, Industrial Marketing, vol. 54 , no. 6 .

Urbanek G., Kosińska E. (red.), 2002, Zarządzanie marka, Polskie Wydawnictwo Ekonomiczne, Warszawa.

Zboralski M., 2000, Nazwy firm i produktów, Polskie Wydawnictwo Ekonomiczne, Warszawa. 